deposited with IUCN, Morges, Switzerland, and Fauna Preservation Society, London, England.]

FRAZIER, John G. (1977). Marine Turtles in the Western Indian Ocean: British Indian Ocean Territory and Comores. Manuscripts, ii +33 , vi +114 pp., 37 figs. [Copies deposited with IUCN, Morges, Switzerland, and Fauna Preservation Society, London, England.]

HIRTH, Harold F. (1971). Synopsis of Biological Information on the Green Rurtle, Chelonia mydas (Linn., 1758). FAO, Rome: Fisheries Synopsis No. 85, pagination various, 15 figs.

HORNELL, James (1927). The Turtle Fisheries of the Seychelles Islands. H.M.S.O., London, England, 55 pp. [Not available for checking.]

HUGHES, George R. (1976). The St Brandon Turtle Fishery. Proceedings of the Royal Society of Arts and Sciences of Mauritius; Sessions 1973-1975, III (Part 2), pp. 165-89, 6 figs.

JACKSON, Peter F. R. (1976). Seychelles asked to continue marine turtle protection. Environmental Conservation, 3(2), p. 138.

JACKSON, Peter F. R. (1977). Continued conservation of Aldabra and Seychelles biota. Environmental Conservation, 4(3), p. 226.

KENYA GOVERNMENT (1962). The Wild Animals Protection Ordinance (Chapter 376). Laws of Kenya. Government Printer, Nairobi, Kenya: pp. 1-41, 1-25.

KENYA GOVERNMENT (1971). The Wild Animals Protection (Amendment of Schedules) Notice, 1971. Legal Notice No. 65. (Chapter 376). Laws of Kenya. Government Printer, Nairobi, Kenya: pp. 5-8.

SALM, Rodney V. (1976). Marine turtle management in Sey- chelles and Pakistan. Environmental Conservation, 3(4), pp. 267-8, 2 figs.

SEYCHELLES GOVERNMENT (1972). The Laws in Force on 31st December 1971; Revised Edition; Chapter 141: Turtles. Government Printer, Port Victoria, Mahé: pp. $161-76$.

SEYCHELLES GOVER NMENT (1977). The Turtles Act (Chapter 141). The Hawksbill Turtles (Protection) Regulations, 1977. Supplement to Official Gazette. Government Printer, Port Victoria, Mahé, p. 237.

STODDART, David R. (1971). Settlement, development and conservation of Aldabra. Philos. Trans. R. Soc. London, Ser. B, 260, pp. 611-28.

TANZANIA GOVERNMENT (1970). Acts Supplement No. 6. An Act to repeal and replace the Fisheries Ordinance and Trout Protection Ordinance, to make provision for the Protection, Conservation, Development, Regulation, and Control, of fish, fish products, aquatic flora, and products thereof, and for matters incidental and connected therewith. Gazette of the United Republic of Tanzania, No. 13, Vol. LI, pp. 35-43.

TANZANIA GOVERNMENT (1975). Subsidiary Legislation; Government Notice Nos. 137 to 140; The Fisheries Act, 1970; Regulations. Gazette of the United Republic of Tanzania, Supplement No. 30, pp. 155-60.

Author adds in proof: The Green Turtles Protection (Amendment) Regulations, 1977 (S.I. No. 51 of 1977), Supplement to Official Gazette, Government Printer, Port Victoria, Mahé, pp. 123-4 has finally been seen by me, and this refers to The Green Turtles Protection Regulations, 1976 (S.I. No. 43 of 1976).

\title{
Oil-spills in the Mediterranean and Contingency Planning
}

For years the use of chemical dispersants in combating oil-spills dismayed many environmentalists as they feared that the toxic products did more harm to marine life than did the spilled petroleum. Research has now led to the use of less dangerous chemicals. Nonetheless, the French held down the use of chemical dispersants in handling the Amoco Cadiz disaster last year, and those they did employ were far less toxic than the chemicals used in the Torrey Canyon disaster 11 years earlier. Even considering the state of pertinent scientific knowledge at that time, the advice followed soon emerged as faulty.

The controversial subject of chemical dispersants was discussed by 34 oil-spill experts from 14 Mediterranean countries and the European Economic Community at a recent Workshop in Malta that was jointly sponsored by the United Nations Environment Programme (UNEP) and the Inter-Governmental Maritime Consultative Organization (IMCO). The Workshop was held at the Regional Oil-Combating Centre on Manoel Island near Valletta, capital of Malta, and there was general agreement among the participants that more studies were needed on the various methods of applying chemical dispersants and on their effects on marine resources.

Although the name of the Centre conjures up images of oil-fighters waiting to rush off in boats with barrels and brooms to a spill anywhere in the Mediterranean, this is not its role. Rather, it is intended to serve as a communications coordination centre in the event of a major spill. Under IMCO's technical guidance, the Malta Centre also gathers information on the national oilcombating capabilities of the 17 states participating in UNEP's Mediterranean Action Plan. In this connection it has compiled a useful inventory of their oil-spill experts and equipment.
The regional Centre encourages Mediterranean countries to draw up national oil-spill contingency plans, disseminates the latest technological information, and helps to arrange for the training of technicians. While it is not considered an operational headquarters, the Centre could, if requested by a country or countries endangered by a major spill, coordinate clean-up action. In this connection it is interesting to note that the Director of the Centre, Philippe Le Lourd, reported to the Workshop on a communications exercise involving the exchange of messages between the Centre and 17 Mediterranean countries between 28 June and 7 July of last year. It was made clear in the initial message that the intention was to test communications in case of an oilspill. Six answers were received within three hours, three more within 24 hours, and three further ones after 24 hours, while five countries did not reply at all. Participants were accordingly asked to find ways of improving communications.

The risk of a major oil-spill is high in the Mediterranean owing particularly to the density of tanker traffic. No individual Mediterranean country could well cope with the consequences of a really catastrophic oilspill. On the other hand, it would not be economically feasible to tie up substantial resources to combat a disaster that might not occur for 10 or even 20 years. Consequently, joint contingency planning by Mediterranean countries seems to be the best method available to deal with any accidental major pollution of the sea by oil.

Paul Evan Ress

European Regional Information Officer

United Nations Environment Programme Palais des Nations

1211 Geneva 10 Switzerland. 